\title{
LONG-RUN IPO PERFORMANCES AND ITS INFLUENCING FACTORS: THE CASE OF INDONESIAN STOCK EXCHANGE
}

\author{
Mahardhini Fuadillah \\ Bank Mandiri Jakarta \\ e-mail:mahardhini@gmail.com \\ D. Agus Harjito \\ Fakultas Ekonomi Universitas Islam Indonesia Yogyakarta \\ e-mail:agus_h@fe.uii.ac.id
}

\begin{abstract}
The objective of this study is to find whether Indonesian stock exchange will also show long-run underperformance of IPO or not, and what are factors influence the long-run underperformance that happens in a company after IPO. Factors influencing IPO performances are represented by four variables are age, time lag, issue size, and company size. Long run IPO performance is represented by Buy-and-Hold Adjusted Return (BHAR). This study employs data from companies listed in Indonesian Stock Exchange (IDX), which are going public from 2000 to 2005. The results show that Indonesian Stock Exchange Market does not show underperformance longrun IPO, and there is a positive relationship between the number of shares offered at the going public period and its long-term performance. However, the other variables used (i.e. age, time lag, and company size) do not influence the long-run IPO performance in Indonesian Stock Exchange.
\end{abstract}

Keywords: initial public offering, long run performance, underperformance

\section{INTRODUCTION}

Initial Public Offering (IPO) is the first time the company's stock is sold to the public (Keown, Martin, Petty, and Scott, 2005). This activity becomes the most important moment for a company, because through IPO a private company will become a public one. It happens when the companies firstly listed their stock in stock market, whereas listed in the primary market, based on the regulation ruled by UU Pasar Modal dan Peraturan Pelaksananya (regulation in Indonesia). Primary market is a market in which new, as opposed to previously issued, securities are traded (Keown, et. al., 2005).

Initial Public Offerings (IPOs) of equity capital are a common activity in financial market around the world. It has a main purpose to raise fund from public (Puk- thuanthong and Walker, 2004). Before the companies go public, there are some requirements that have to be fulfilled by the companies. Some of the requirements, the first is companies have some alternatives of fund sources, from either inside of the company or outside of the companies. And the second, before the companies go public, they should make some internal preparation and prepare some documents that will be used to fulfill the go public requirements, and all the requirements from BAPEPAM (Badan Pengawas Pasar Modal). And after they have been listed in the capital market, the companies have to obey all regulation made by Capital Market.

There is a change of some conditions inside the companies during the IPO process so the companies do not only have to make 
preparations before the listing process, but also some preparations in order to face the changes after they are listed in capital market. A change known as one of the disadvantages of the IPO process is the share ownership of the company. Before they are listed in capital market, the owner of a company has a full ownership toward the company. However, after they are listed in the capital market the owner has to share his ownership with the shareholders because the shareholders have some parts of the company ownership. Some companies who want to go public at the first time will feel worried if they will loose the company control. Even though there is a disadvantage of the IPO process, there are actually a lot of advantages that they can get from go public process. Beside they can raise their fund from outside investors, the regulations that they have to obey are not too difficult and the process is not so complicated, even for small companies. Some of the regulations are such as companies that had have been operated at least 12 years, have net asset at least Rp 5 billion with audited financial statement, and sell at least 50 million stock share.

The changes that happen inside the company after IPO will lead changes to the company performance, whether in short-run or long-run period after the IPO, if the companies are not able to know those changes and how to anticipate the changes. This financial transaction seems simple and normal enough, but there are some interesting phenomena that make a lot of researchers interested to find the answer. The first is that the price of the issue price of a newly listed company's share is below the price at which the share trades in the secondary market at the first time, or known as underpricing. And the second is the poor long-term return performance of IPOs compared to the stock market, or it is usually called the long-run underperformance. This last phenomenon will be the condition that will be analyzed in this research.

Long-run performance of IPO is a performance of IPO that is being analyzed in the long-run periods, which is two until three years or more after the listing date. A long-run underperformance is a condition of long-run performance of IPO, which shows a decline from year to year. So if there is a comparison between the performance of IPO in short term (just few days after listing date) and the long term, the data will show that the long run IPO has worse performance than the short term. Ritter (1991) explained that there are some possible explanations for the underperformance condition; they are risk miss-measurement, bad luck, and fad and over-optimism. He also concluded that this condition indicates that the offering price is not too low, but the first aftermarket price is too high. On the other hand, a lot of findings showed that the higher the underpricing in the initial return, the higher underperformance happened in that stock exchange market (Corhay, Teo, and Rad, 2002; Goergen, Khurshed, and Mudambi, 2007).

This study also want to find whether Indonesian stock exchange will also show long-run underperformance of IPO or not, and what factors influence the long-run underperformance that happens in a company after IPO are. By analyzing some factors based on some previous findings, this research wants to give guidance for the companies who want to go public in preparing some decisions in order to face the changes that may happen so that the long-run underperformance that will happen in the future can be anticipated.

IPO is a well-known financial activity that has been done by a lot of companies. This financial activity becomes more important and holds an important role in the companies in rising fund from the external company. When companies need huge money, while they cannot fulfill those needs with the internal ability, they will do IPO or sea- 
soned equity (seasoned new issue). A seasoned new issue refers to stock offerings by companies that already have common stocks that are traded in the secondary market.

This important activity hopefully can help a better performance of the companies. But if underperformance long-run condition happens, it means that IPO is not a good decision in order to raise more fund for the company. The underperformance condition almost happens in every part in this world, like what Ritter (1991) showed in the U.S, Bessler and Thies (2007) concluded in Germany, or in the other developed markets, and even in the emerging market such as in Sri Lanka (Peter, 2007), China (Gu, 2003), and Greek (Thomadakis, Nounis, and Gounopoulos, 2007; Gounopoulos, Nounis, and Stylianides, 2005). And the research comparison of IPO performance in emerging markets was also conducted by Pracianoy and Cigerza (2007).

A position of IPO procedures is no longer able to fulfill its previous purpose to help companies raising funds from the external parties, if long-run underperformance happens in the market. There is no previous research conducted to analyze long-run underperformance of IPO in Indonesian Market condition. This condition makes a lot of companies in Indonesia unaware of this phenomenon. They do not realize that IPO is no longer a good decision to raise more funds for the company. It needs some treatments and analysis to make a better condition.

IPO long-run underperformance also becomes an important condition to be understood by every investor. Investors sometimes do not understand that even though they earn a large positive abnormal returns in the early aftermarket period, the returns will be diminishing after two or three years of listing. Investors should understand the real condition of the market, so they will not only buy IPO to look for large abnormal returns, but they can also be more sensitive to every market change, and help the companies raising their fund.

This study is conducted to find whether Indonesian Stock Exchange shows long-run underperformance or not, and if it is "yes", what factors that make those conditions happen are. Goergen, et. al. (2007) concluded that there are relationships between IPO and the pre-IPO financial performance, and also with the managerial decision taken before IPO. Thus, through this research there are two objectives that will be accomplished: (1) To get information about long-run performance of IPO in Indonesian Stock Exchange, and (2) to know factors influencing IPO long-run performance.

\section{LITERATURE REVIEW}

The poor long-run performance of IPO only happened in some companies, while the other companies show positive long-run (Bessler and Thies, 2007), so every company will not show the same long-run underperformance condition. Based on this condition, a lot of researchers are interested in finding the reasons why some companies show underperformance in the long-run IPO, while the others do not. Beatty and Ritter (1986) found that while underpricing is common, the "need" for and extent of underpricing is reduced if the uncertainty about the IPOs future cash flow is reduced. This condition makes many researchers want to examine the role of financial and non financial characteristics of IPOs in explaining initial day underpricing and long term underperformance, like what Dimovski and Brooks (2004) did. They examined financial and non-financial factors that influence the IPO long-run underperformance in Australia, while the other researchers are more interested in the non-financial factors. Goergen, et. al. (2007) concluded that there are relationships between IPO and the pre-IPO financial performance, and also with the managerial decision taken before IPO, be- 
side the other factor.

There are various characteristics that have been investigated in previous researches. Dimovski and Brooks (2004) use both financial and non-financial factors, which are offer price, capital sought, market sentiment, share options, underwritten, EPS yield, DPS yield, franking and DRP, underwriter options, capital retained, and limited liability. They found that only market sentiment and the underwriter options have positive coefficient, while share option and DPS yield have negative coefficient relationship.

A unique research was conducted by Alvarez and Gonzalez (2001). They believed that the result of long-term IPO performance examination depends on the methodology used, and then they compared three different methods. This finding is supported by Brav and Gompers (1997), which the result of Buy-and-Hold Adjusted Returns (BHAR) is different from the Fama-French's model in explaining the long-run underperformance, and the BHAR gives different result if it is compared to Average Monthly Market Adjusted Return (MMAR) (Pracianoy and Cigerza, 2007). According to Stevenson (2006), the privatization has greater degree underpriced than private sector firms, but tends to be more out-performed in the long term.

The trust to the government will also influence the long-run performance of the IPO. If investors distrust the government involving in the business operation and more confident for the privatization of state enterprise, they will have lower return $(\mathrm{Gu}$, 2003). Whereas the investors trust to the government, IPOs will have better long-run performance (Steen and Kendall, 2004). There are still a lot of variables that can be used to define the underperformance condition in long-run IPO, such as time period chosen (Bessler and Thies, 2007; Tsangarakis, 2004), ownership structure (Yeh, Shu, and Guo, 2008; Li and Hovey, 2007), time lag (Thomadakis, et. al., 2007), size of issue (Gounopoulos, et. al., 2005), family owned (Jaskiewicz, Gonzalez, Menendez, and Schiereck, 2005; Chahine, 2007), etc.

This research will only take some of those factors to be used as the indicator (independent variable); which are age, time lag, issue size, and company size. This study chooses those variables, because they have been represented almost another variable. For example, the family-owned companies usually seem like a small young company. The family members have strong controls. The family-owned company has become the part of company size, ownership structure, and this will influence which the underwriter is used.

\section{Indonesia IPO's Long Run Performance}

Underperformance condition happens almost in every part in this world, like what Ritter (1991) showed in U.S, Bessler and Thies (2007) concluded in German, or in the other develop markets, and even in the emerging market such as in Sri Lanka (Peter, 2007), China (Gu, 2003), and Greek (Thomadakis, et. al., 2007; Gounopoulos, et. al., 2005). And the research comparison of IPO performance in emerging market has also conducted by Pracianoy and Cigerza (2007).

The previous researches explained above were conducted in both developed market and emerging market. Indonesia is included in the emerging market because Indonesia is a developing country. Based on this situation, this study assumes that Indonesia will have the same IPO long-run performance with the other emerging markets. The previous research conducted in emerging markets showed that long-term performance of IPO in most of emerging markets is in an underperformed condition. Peter (2007) conducted a research in Sri Lanka, which relatively has small stock market compared with the other country. The result showed that in the third year, Sri Lanka un- 
derperforms $-12.9 \%$. In Greek, the market was in underperformed condition by $-1.24 \%$ after three years of listing (Thomadakis, et. al., 2007). While in Cyprus, a $-64.40 \%$ underperformance happened in the third year of listing (Gounopoulos, et. al., 2005).

Age

The age of the issuing firm calculated as the difference between the date of registration and the date of listing (Goergen, et. al., 2007). The operating history of a firm prior to going public plays a significant role to its stock price performance (Thomadakis, et. al., 2007). An old company has longer operating history and more information available to the public, neither is young company (Gounopoulos, et. al., 2005). Hence, age influences the long-run IPO performance of a company positively. This condition will influence the long-run underperformance negatively. In the case of family-owned business, the older the firm means the more problems will happen because of multi-generation. This will positively influence the long-run underperformance (Jaskiewicz, et. al., 2002). The condition will make the old company's long-run IPO performance worse than the younger one.

\section{Time Lag}

The time lag is the period between the official date of the prospectus announcement (or offer price date) and the listing date of an IPO (Thomadakis, et. al., 2007). It usually starts about four weeks later. This time lag has negative implication for both underwriter and the buying investor. For underwriter, the trading lag will need more distribution cost, to wait before the securities can be able to entry the secondary market. While the investor will get uncertainty, because they have to wait (need more time) to know the actual market value of their purchase security or before can liquidate it in the secondary market (Tsanga- rakis, 2004). During this period, there are any possibilities of the market condition of economy changing that will affect the price performance, in the initial or after market (Thomadakis, et. al., 2007). Thomadakis, et. al. (2007) showed that there is negative effect of time lag to the long-run IPO performance. If time lag increases, it means that the uncertainty about the IPO valuation and listing increases and this will lead the worse long-run underperformance (Gounopoulos, et. al., 2005).

\section{Issue Size}

Issue size is defined as the number of share that is offered and the offer price issued (Gounopoulos, et. al., 2005). The size of an IPO can be used as a proxy variable for uncertainty about the ex post value of IPOs (Thomadakis, et. al., 2007). Previous studies used the size of issue to control the issuer's overall risk and issue uncertainty. Better-established firms often make larger issues and this large numbers of share are generally less risky than the smaller (Guo, Lev, and Shi, 2006). According to Brav and Gompers (1997), the long-run performance of non-venture backed IPOs are below than the other in the one until five-years. And the results show that small issuers drive that underperformance of non-ventured backed IPO. There is a finding that size of IPO is negatively related to the cumulative adjusted market return, which will lead less long-run underperformance (Corhay, et. al., 2002). The smaller the size of an IPO, the higher the IPO cumulative market adjusted return, because size is positively correlated to reputation, and more reputable firms will raise more money thus there is no need to underprice as much as smaller firms.

\section{Company Size}

Large company has a negative relationship to the poor long-run performance. Drobetz, Kammermann, and Walchli (2005) 
said that in Swiss, IPO has poor long-run performance, in both of using BHAR and CAR, and the fact showed that those firms tend to be small firms. Gounopoulos, et. al. (2005) said that smaller firms tend to be more risky. Larger firms have a higher association with a larger flow of external information and the market's expectation is related to firm size. There was investigation to the family owned businesses that are small, have more negative long-run performance (Jaskiewicz, 2005). That result has been supported by Chahine (2007) who said that family owned business had a strong blockholder (defined as the largest share holder ownership) toward their business. This condition will make the company difficult to accept investors from the outside. This condition will lead the decreasing trust from the investor. Moreover, Jaskiewicz, et. al. (2005) showed that the family-owned company cannot be indicated as a small business and gives the significance long-run underperformance.

Large company usually used reputable underwriting, while the small company will use not-reputable underwriter or even self-underwritten. The companies that used self-underwriting and have poor long-run performance are the companies who issued the non-penny stock or small company
(Dempere, 2008). Bradley, et. al. (2006) also investigated the penny and non-penny stock, which is divided the research into the small (non-penny stock) and large companies (penny stock). Chin, Lee, Kleinman, and Chen (2006) showed that the innovation has strongly positive effect to give better result in long-run performance, while large company does innovation in Research and Development (RandD). On the other research showed, big company will need higher transaction cost in doing IPO (Ritter, 1991). It will mean nothing because they meet difficulties in raising their fund, and will influence the stock price performance. While small companies do not necessarily face a higher cost of equity capital. This study assumes that company size actually has a relationship with long-run performance of IPO. The total asset of the company defines this company size in the date of listing.

\section{Theoretical Framework and Hypotheses Development}

This study uses two groups of indicators that represent the long run performance of IPO and factors influencing it to measure the relationship between long run performance of IPO and the influencing factors. The formulas are as follows:

Table 1: Indicator and Proxies of the Research

\begin{tabular}{ll}
\hline \multicolumn{1}{c}{ INDICATORS } & \multicolumn{1}{c}{ PROXIES } \\
\hline $\begin{array}{l}\text { Long run performance of IPO (Buy-and-Hold } \\
\text { Adjusted Return) }\end{array}$ & $\begin{array}{l}\text { Closing price of first day of trading Closing } \\
\text { price of each time period used Indonesian Com- } \\
\text { pound Index (IHSG) of first day of trading Indo- } \\
\text { nesian Compound Index (IHSG) of each time } \\
\text { period used }\end{array}$ \\
Factors influencing long run performance of IPO & $\begin{array}{l}\text { Age of Company Time Lag Issue Size (amount } \\
\text { of share) Company Size }\end{array}$ \\
\hline
\end{tabular}


Some previous researchers, who conduct research in some emerging market in the world, showed that there are significant underperformance conditions in those countries. It was showed in the research conducted by Peter (2007) in Sri Lanka, Thomadakis, et. al. (2007) in Greek, and Gounopoulose, et. al. (2005) in Cyprus. From those researches, this study assumes that Indonesia as an emerging market will also have a same long-run IPO performance with those three countries. Thus this study formulate the hypotheses as follows:

H1: Indonesian Stock Exchange Market shows underperformance long-run IPO.

There are some factors that will influence the performance of long-run IPO. In this research, there are four factors that will be analyzed. The first factor is age of the company (Age). Thomadakis, et. al. (2007) said that old of a firm plays a significant role, because an older company, will have more experience in running the business. An old company will also has longer operating history and more information available to the public (Goergen, et. al., 2007), thus the public can get the information about the company easily. So, looking at those results, this study formulate the hypotheses as follows:

$\mathrm{H} 2$ : The older the firm, the better the longrun performance of IPO.

The second factor is Time Lag, a period between the offer price date and the listing date of an IPO. According Tsangarakis (2004), the longer the time period, the more worry the investor. That is because the investor will get uncertainty in that waiting time, while there are any possibilities of the changes of market condition during the waiting time (Thomadakis, et. al., 2007). Thus, this study formulate the hypotheses as follows:

H3: The longer the waiting period of a firm to go public, the lower the long-run performance.

The next factor is Issue Size (IS), the size of the stock. Issue Size is being used as proxy variable for uncertainty about the ex post value of IPOs (Thomadakis, et. al., 2007). The more the Issue Size, the lower the uncertainty of ex post value. A betterestablished firm also will issue a large number of shares, which is less risky than the smaller one (Guo, et. al., 2006). Thus, a large number of stocks offered will lead a lower underperformance of long-run IPO. Thus, this study formulate the hypotheses as follows:

H4: There is a positive relationship between the size of stock (number of share) at the going public period and its longterm performance.

The last factor is Company Size (CS). Gounopoulos, et. al., (2005) said that smaller firms tend to be more risky. Chahine (2007) who said that family owned business had a strong block-holder (defined as the largest share holder ownership) toward their business, while the family owned businesses, that are small, have more negative long-run performance (Jaskiewicz, 2005). Thus, the size of the company (CS) will influence the long-run IPO performance positively. Thus, this study formulate the hypotheses as follows:

H5: The company size will influence the long-run performance positively. 


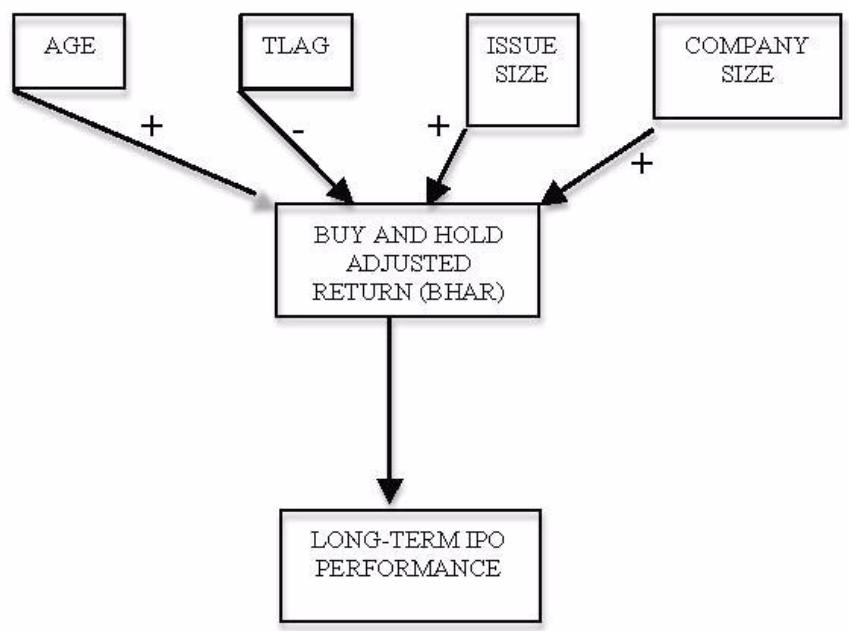

Figure: 1. Theoretical Frameworks Chart

This research contains two stages. The first stage is calculated Buy-and-Hold Adjusted Return to know the long-run IPO performance in Indonesian Stock Exchange. The second one, using multiple regressions, assesses the influencing factor's relationship with long-run IPO performance in Indonesian Stock Exchange Market.

\section{RESEARCH METHOD}

This research uses quantitative secondary data because the data are reported numerically and taken from Pojok BEJ in Faculty of Economics, Universitas Islam Indonesia, which has real time on line with Indonesian Stock Exchange in Jakarta. There are also two kinds of quantitative data, which are discrete and continues data. Discrete variables assume only for certain values, and usually there is a gap between the values. This variable comes from counting process. While continues variables can assume any values in any specific range, and it comes from measurement process. For this study, the researcher uses continues data.

In this research, there are two kinds of test used. Which are behavior analysis, and causality test. The behavior analysis is a test to observe long run performance of IPO in Indonesian Stock Exchange (IDX) and uses a particular formula to know the IPO's pattern of long run performance in IDX. And, the causality test is used to analyze the performance of each factor toward the long run performance of IPO. In this test there are one independent variable and four dependent variables. The independent variable is Buy-and-Hold Adjusted Return (BHAR), as the method of long run performance of IPO. The dependent variables are Age, Time Lag, Issue Size, and Company Size. This study uses a multiple regression to find the relationship among those variables.

\section{Indonesian Market Condition}

To find whether Indonesian market condition show a long-run underperformance or not, this research will calculate it by using Buy-and-Hold Adjusted Return (BHAR) method. It is calculated by using two criteria that are used in international literature: the raw and the excess or adjusted returns (Thomadakis, et. al., 2007). This research will calculate the market adjusted return of three-year period for each company in the time period used in this research. 
This study will calculate the Buyand-Hold Adjusted Return based on the listing price of IPO, and the returns are calculated by using this following time points:

1. The first day trading period in the IDX (Indonesian Stock Exchange)

2. The six month trading period in the IDX (the $126^{\text {th }}$ day of trading)

3. The one year trading period in the IDX (the $250^{\text {th }}$ day of trading)

4. The one and a half year trading period in the IDX (the $376^{\text {th }}$ day of trading)

5. The two-year trading period in the IDX (the $500^{\text {th }}$ day of trading)

6. The two and a half year trading period in the IDX (the $626^{\text {th }}$ day of trading)

7. The three-year trading period in the IDX (the $750^{\text {th }}$ day of trading)

(Note: $1^{\text {st }}, 2^{\text {nd }}$ and also $3^{\text {rd }}$ time points are defined as the short term IPO. If the result is true, only the $4^{\text {th }}, 5^{\text {th }}, 6^{\text {th }}$ and also $7^{\text {th }}$ of time points that are significant defined as long-run IPO performance).

Those time points are being used to make this research easier to conduct and analyze the data. This research analysis the performance of Buy-and-Hold Adjusted Return (BHAR) of IPO until three years after go public, because it will be very difficult if daily data is being analyzed. Those time points do not only to help the process of this research, but also want to define the long-run period of IPO. This research defines the long-run period of IPO performance as the performance a year after the listing date. The

To define whether Indonesian Stock Exchange Market shows underperformance in the Initial Public Offering process in long-run condition, the market adjusted return will show negative and more negative in the following year, or we can say that the performance of market adjusted return in IPO process decreases after three-years. It can be seen by using Mean Compare Test
(One Sample t-test) for every year in threeyear period. The criteria used to reject or approve the hypotheses are if $\mathrm{p}$ (mean adjusted return each year) $<\alpha(0.05), \mathrm{H} 0$ is rejected; but if $\mathrm{p}$ (mean adjusted return each year) $>\alpha(0.05) \mathrm{H} 0$ is accepted. At the same time, mean adjusted return $\mathrm{t} 1>$ mean adjusted return $\mathrm{t} 2>$ mean adjusted return $\mathrm{t} 3>$ mean adjusted return $\mathrm{t} 4>$ mean adjusted return $\mathrm{t} 5>$ mean adjusted return $\mathrm{t} 6>$ mean adjusted return $\mathrm{t} 7$, where $\mathrm{t}$ shows time points that will be used in this research.

\section{Influencing Factors}

On the other hand, to find the relationship between each factor and the longrun performance, this research will use the multiple regression method of each factor. The criteria used to reject or approve the hypotheses are if p (AGE, TLAG, IS, CS) < $\alpha(0.05)$, or we can say that $p$ of each variable is less than $\alpha(0.05)$, then the nullhypotheses (H0) is rejected; but if p (AGE, TLAG, IS, CS ) > $\alpha(0.05)$, then the nullhypotheses (H0) is accepted. And the standard coefficient (Beta) is used to define the relationship (whether positive or negative) between each independent variable and the dependent one (market adjusted return).

\section{Research Subject}

As the population, this research will use companies listed in Indonesian Stock Exchange Market. The researcher limits the sample to companies doing IPO from 2000 to 2005. This study uses this sample because the condition after 1998 crisis and before America's 2007 crisis makes the company's condition at that time more flexible than conditions during the crisis. Thus, the condition can be more acceptable. Data will be observed for 3 years after listing date. Those companies have different years of listed, thus the data must be collect based on the year of each company. 
The sample of this study is derived from a sampling method; it means that the sample is selected by using some particular criteria. The criteria used are:

1. This study is conducted to private and public companies listed on Indonesian Stock Exchange.

2. The samples are the companies doing IPO from 2000 until 2005.

3. The sample will be observed for 3 years after the listing date.

\section{Research Variables}

There are two kinds of variables used in this research, dependent and independent variables. Long-run performance of IPO measured by Buy-and-Hold Adjusted Return (BHAR) method acts as the dependent variables. On the other hand, Age of the Company (AGE), the Time Lag (TLAG), Issue Size (IS), and Company Size (CS) are independent variables.

\section{Technique of Data Analysis \\ Buy-and-Hold Adjusted Return}

The Buy-and-Hold Adjusted Return (BHAR) that is defined as the raw return minus the corresponding market return is calculated by (Thomadakis, et. al., 2007): BHARi,t $=$ Raw return i,t - Market return $_{i, t}$. Raw return is the individual return for each company, while market return is the average return from all company that is listed in stock exchange market (in this case is in Indonesian Stock Exchange Market). From that formula, we can know that if a company's raw return is more than the market return, which will result a positive BHAR, thus it means that the performance of that company is better than the average performance of company listed in stock exchange market. On the other hand, if the BHAR is negative, because the company's raw return is lower than the market return, it means that the performance of that company is worse than the average performance of company listed.

\section{Raw Return}

The proportion return or the raw return of the IPO trading is calculated by (Thomadakis, et. al., 2007):

Raw $=\frac{\begin{array}{c}\text { (Closing priceof } n \\ \text { day trading) }\end{array}-\begin{array}{c}\text { (Closing priceof } \\ \text { first day of trading) }\end{array}}{\text { Closing price of first day of trading }}$

where:

$\mathrm{n}=$ the day of trading that the long-run calculated performance is based

\section{Market Return}

The market return is calculated as follows (Thomadakis, et. al., 2007):

Market return $=\frac{\mathrm{IHSG}_{1}-\mathrm{IHSG}_{0}}{\mathrm{IHSG}_{0}} \times 100 \%$

IHSG = Compound Index (Index Harga Saham Gabungan), it is a general market index in Indonesian Stock Exchange. $0=$ the base point, while $1=$ the end point for the calculation of the return IHSG0 = IHSG taken in the closing price of $\mathrm{n}$ day IHSG1 = IHSG taken in the $\mathrm{n}-1$ day of trading

\section{Multiple Regression}

The regression that being used is (Thomadakis, et. al., 2007): BHARt $=\mathrm{a}+\beta 1(\mathrm{AGE})+\beta 2(\mathrm{TLAG})+\beta 3$ $(\mathrm{IS})+\beta 4(\mathrm{CS})+$ ciWhere $\mathrm{t}=$ time point used in this research and $\varepsilon i=$ error term

From that model, we can see that AGE, TLAG, IS and CS will influence BHAR as $\beta 1, \beta 2, \beta 3$, and $\beta 4$ respectively. It is mean that if there is a change AGE as one, the BHAR will changes as $\beta 1$, while if there is a change of AGE as two, the BHAR will change as $2(\beta 1)$, and so on. From the hypothesis, AGE, IS, and CS will influence BHAR positively, it means that the $\beta 1, \beta 3$, and $\beta 4$ will positive, while $\beta 2$ will negative because TLAG influences BHAR negatively. 


\section{RESULTS AND DISCUSSION}

This session discusses about the research and the deep implication and explains about the measurement of variables used in this research, the analysis of data and the interpretation of hypotheses testing that contain explanation of research findings, implication and research implication.

The samples used in this research are companies doing IPO from 2000 to 2005. From the total of 103 companies did IPO in Indonesian Stock Exchange at that time, only 84 companies that fulfill the requirements needed in this research, because some of data needed are not available in Pojok $B E J$ that have real time online connection with Indonesian Stock Exchange in Jakarta.

\section{Descriptive Statistics}

This descriptive statistics is used to define the total sample, the minimum of the data, maximum of the data, the mean the data, and the standard deviation of the data for each variable. From this descriptive statistics, it shows the summary of data used in this research.

Table 2 shows the number of data being used in this research is 84 . As explained before that there are only 84 companies that fulfill the requirement needed from the total number of 103 companies listed in Indonesian Stock Exchange (IDX) during 20002005. The table 2 shows the minimum, maximum, mean and standard deviation of data for each variable being used.

Table 2: Table of Descriptive Statistics

\begin{tabular}{llllll}
\hline & $\mathrm{N}$ & \multicolumn{1}{c}{ Minimum } & \multicolumn{1}{c}{ Maximum } & \multicolumn{1}{c}{ Mean } & \multicolumn{1}{c}{ Std. Deviation } \\
\hline Age TLAG Issue & 84 & $0-11$ & 2097346 & 17.20 & 26.557 \\
Size Company Size & 84 & 30000000 & $5 \mathrm{E}+009$ & 110.01 & 799.997 \\
BHAR 1st day & 84 & $2 \mathrm{E}+010-$ & $4 \mathrm{E}+014$ & $3 \mathrm{E}+008$ & 712364456.7 \\
BHAR 6th month & 84 & $3.1763-$ & 10.3571 & $1 \mathrm{E}+013$ & $5.735 \mathrm{E}+013$ \\
BHAR 1st year & 84 & $93.2632-$ & 343.6779 & 0.113623 & 1.7783084 \\
BHAR 1.5th year & 84 & $98.1667-$ & 478.0574 & $1.580787-$ & 70.2294039 \\
BHAR 2nd year & 84 & $97.7584-$ & 210.0139 & $4.095999-$ & 81.9821491 \\
BHAR 2.5th year & 84 & $98.7926-$ & 368.3598 & $14.5297-$ & 66.6892764 \\
BHAR 3rd year & 84 & $99.0516-$ & 563.9123 & $2.239194-$ & 91.6516877 \\
& 84 & 98.4784 & 653.4606 & $4.425551-$ & 102.4889879 \\
& 84 & & & 4.958079 & 113.6176624 \\
\hline
\end{tabular}

Source: Primer data, 2009

\section{Compare Mean Test}

Table 3: Compare Mean Test

\begin{tabular}{llll}
\hline \multicolumn{1}{c}{ Variables } & t-Stat & Prob. & Result \\
\hline BHAR 1st & 0.586 & 0.560 & H0 is accepted \\
BHAR 6 month & 0.206 & 0.873 & H0 is accepted \\
BHAR 1st year & -0.458 & 0.648 & H0 is accepted \\
BHAR 1.5th year & -1.997 & 0.049 & H0 is rejected \\
BHAR 2nd year & -0.224 & 0.823 & H0 is accepted \\
BHAR 2.5th year & -0.396 & 0.639 & H0 is accepted \\
BHAR 3 year & -0.400 & 0.690 & H0 is accepted \\
\hline
\end{tabular}

Source: Secondary data, 2009 
To know whether Indonesian market condition shows an underperformance or not, this study uses compare mean test using one-sample t-test method in SPSS program. The result shows as Table 3 .

From Table 3 above, only Buy-andHold Adjusted Return (BHAR) in the $1.5^{\text {th }}$ year that is significant, because the p-value $(0.049)$ is below the $\alpha(0.05)$, while the others are above the $\alpha$. Thus, only HO in the $1.5^{\text {th }}$ year is rejected. This research defines the long-run IPO performance as the performance of Buy-and-Hold Adjusted Return (BHAR) after one year listed in Indonesian Stock Exchange (IDX). From the time point used in this research, the table 4.2 shows and proves that only BHAR in the $1.5^{\text {th }}$ year is significant showing a long-run underperformance condition, where the t-Stat is -1.997 . Based on the hypotheses, this research concludes that $\mathrm{HO}$ is accepted. Thus, it can be concluded that Indonesian market condition does not show long-run IPO underperformance. It can be seen that the model used in this research shows insignificant results of long-term underperformance condition in Indonesia, because the other long-run period of IPO $\left(2^{\text {nd }}\right.$ year, $2.5^{\text {th }}$ year, and $3^{\text {rd }}$ year $)$ do not show significant results. However, the data shows that Indonesian market condition is underperformance in long-term, since tStat of $\mathrm{t} 1$ (BHAR in the $1^{\text {st }}$ day) $>\mathrm{t}$-Stat of $\mathrm{t} 2$ (BHAR in the $6^{\text {th }}$ month) $>$ t-Stat of $\mathrm{t} 3$ (BHAR in the $1^{\text {st }}$ year) $>$ t-Stat of $t 4$ (BHAR in the $1.5^{\text {th }}$ year) $>\mathrm{t}$-Stat of t5 (BHAR in the $2^{\text {nd }}$ year) $>$ t-Stat of t6 (BHAR in the $2.5^{\text {th }}$ year) $>$ t-Stat of $\mathrm{t} 7$ (BHAR in the $3^{\text {rd }}$ year). This condition is consistent with the result found by Goergen, et. al. (2007), where long-run IPO performance is not significant in U.K.

This happens because of the previous research finding conducted in countries that have a worse condition than Indonesia (Sri Lanka and Cyprus). Peter (2007) said that Sri Lanka's stock market is relatively small compared with the other country, even compared with some regional markets in South Asia, while Cypriot is the smallest market the international evidence that has ever searched (Gounopoulos, et. al., 2005). That is why the market performance shows underperformed condition in three years after listing and after twelve-months listed in Sri Lanka and Cyprus respectively. Indonesia is the country that has bigger and better market condition.

In Gounopoulos, et. al. (2005), there is data that show International Empirical Evidence of some countries in the world. The data shows that companies, which have very good financial performance or bad financial performance, tend to have lower long-run IPO performance. While companies, which have an average financial performance, are having better long-run IPO performance. It was showed that U.S has $20.0 \%$ and Japan has $-27.0 \%$ of long term returns, while Korea and Singapore have $4.64 \%$ and $-9.2 \%$ of long-term returns respectively.

The other reason that could be explained is that this insignificancy is the method that is used. Alvarez and Gonzalez (2001) explained that the result of long-term IPO performance examination depends on the methodology used. This finding is supported by Brav and Gompers (1997) in which the result of Buy-and-Hold Adjusted Returns (BHAR) is different from the FamaFrench's model in explaining the long-run underperformance. BHAR also gives different result if it is compared to Average Monthly Market Adjusted Return (MMAR) (Pracianoy and Cigerza, 2007). It might be needed more time points to show a long-run IPO underperformance in Indonesia, because $\mathrm{Gu}$ (2003) showed that China had a long-run IPO underperformance five years after go public. 


\section{Regression Result}

This research analyzes the performance of IPO in Indonesia for long term. Thus this study examines the condition of each company for three years. The condition causes the three-year analysis, the results shown in Table 4.

In the first day, the Buy-and-Hold Adjusted Return is showed as above. From the data we can see that this regression is not significant, because the p-value is 0.571 . The factors that influence the regression (BHAR in the first day) are also not significant because all of the p-values are more than $\alpha(0.05)$. Thus, we can say that based on BHAR in the first year, H0 is accepted. It means that all of the factors are not related with the long-run IPO performance in the first day.

Table 4: BHAR in the first day (t1)

\begin{tabular}{lccccc}
\hline \multicolumn{1}{c}{ Variables } & Coefficient & Std. Error & t-Stat & Prob. & Result \\
\hline C & 0.241 & 0.248 & 0.974 & 0.333 & H0 is accepted \\
Age & 0.001 & 0.008 & 0.009 & 0.993 & H0 is accepted \\
TLAG & -0.013 & 0.000 & -0.116 & 0.908 & H0 is accepted \\
Issue Size & -0.252 & 0.000 & -1.656 & 0.102 & H0 is accepted \\
Company Size & 0.215 & 0.000 & 1.407 & 0.163 & H0 is accepted
\end{tabular}

Dependent variable $=\mathrm{BHAR}_{1} ;$ Probability $=0.571$ and $\mathrm{R}^{2}=0.036$

Table 5: BHAR in the $6^{\text {th }}$ month (t2)

\begin{tabular}{lccccc}
\hline \multicolumn{1}{c}{ Variables } & Coefficient & Std. Error & t-Stat & Prob. & Result \\
\hline C & -9.272 & 9.640 & -0.962 & 0.339 & H0 is accepted \\
Age & 0.136 & 0.298 & 1.203 & 0.233 & H0 is accepted \\
TLAG & -0.091 & 0.010 & -0.829 & 0.409 & H0 is accepted \\
Issue Size & 0.188 & 0.000 & 1.253 & 0.214 & H0 is accepted \\
Company Size & -0.045 & 0.000 & -0.299 & 0.766 & H0 is accepted \\
\hline
\end{tabular}

Note: Dependent variable $=$ BHAR2; Probability $=0.272 ; \mathrm{R}^{2}=0.062$

Table 6: BHAR in the $1^{\text {st }}$ year $(\mathrm{t} 3)$

\begin{tabular}{lccccc}
\hline \multicolumn{1}{c}{ Variables } & Coefficient & Std. Error & t-Stat & Prob. & Resul \\
\hline C & -17.857 & 11.099 & -1.609 & 0.112 & H0 is accepted \\
Age & 0.062 & 0.343 & 0.557 & 0.579 & H0 is accepted \\
TLAG & -0.048 & 0.011 & -0.447 & 0.656 & H0 is accepted \\
Issue Size & 0.316 & 0.000 & 2.131 & 0.036 & H0 is rejected \\
Company Size & -0.069 & 0.000 & -0.462 & 0.645 & H0 is accepted \\
\hline
\end{tabular}

Dependent variable $=$ BHAR3; Prob. $=0.118 ; \mathrm{R} 2=0.088$ 
From the table above, it can be seen that BHAR in the $6^{\text {th }}$ month shows almost similar condition with BHAR in the first day, where the p-value $(0.272)$ is more than $\alpha(0.05)$. It also happens with all $p$-values of each factor. This makes the regression in this time point not significant. So, in this second time point (BHAR in $6^{\text {th }}$ month), the $\mathrm{HO}$ is also accepted. This condition makes this research conclude that all of the factors are not related with the long-run IPO performance in Indonesia $6^{\text {th }}$ month after go public.

The same as the two previous conditions, BHAR in this third time point also shows an insignificant condition, where the p-value is 0.118 , more than $0.05(\alpha)$. However there is a different condition compared with the previous one, where Issue Size factor is significant because the p-value is more than 0.05. The Issue Size influences the long-run performance of IPO positively which is 0.316. Moreover, the H0 is still accepted because the overall p-value is below 0.05, which means insignificant. It means that all of the factors are not related with the long-run IPO performance in Indonesia.

Different from the previous conditions, in this time point the regression starts to be significant because the $\mathrm{p}$-value shows 0.000 where it is below the $\alpha(0.05)$. Thus this research concludes that in this time point (BHAR in the 1.5 year) $\mathrm{H} 0$ is rejected. The data also shows that only Issue Size that significantly influences the long-run IPO performance positively. This condition is consistent with the previous condition in the first year (t3) of Buy-and-Hold Adjusted Return. It means that actually all of the factors are related to or influence the long-run IPO performance in Indonesia, but only Issue Size that gives a significant influence, while the others are influencing the performance insignificantly.

Table 7: BHAR in the $1.5^{\text {th }}$ year $(\mathrm{t} 4)$

\begin{tabular}{llllll}
\hline Variables & Coefficient & Std. Error & t-Stat & Prob. & Result \\
\hline C & -35.704 & 7.821 & -4.565 & 0.000 & H0 is rejected \\
Age & 0.116 & 0.242 & 1.204 & 0.232 & H0 is accepted \\
TLAG & -0.004 & 0.053 & 0.572 & 0.569 & H0 is accepted \\
Issue Size & 0.536 & 0.000 & 4.176 & 0.000 & H0 is rejected \\
Company Size & -0.022 & 0.000 & -0.174 & 0.862 & H0 is accepted
\end{tabular}

Dependent variable $=$ BHAR4; Prob. $=0.000 ; \mathrm{R}^{2}=0.316$

Table 8: BHAR in the $2^{\text {nd }}$ year (t5)

\begin{tabular}{lccccc}
\hline \multicolumn{1}{c}{ Variables } & Coefficient & Std. Error & t-Stat & Prob. & Result \\
\hline C & -22.455 & 11.901 & -1.887 & 0.063 & H0 is accepted \\
Age & 0.082 & 0.368 & 0.767 & 0.445 & H0 is accepted \\
TLAG & -0.074 & 0.012 & -0.718 & 0.475 & H0 is accepted \\
Issue Size & 0.392 & 0.000 & 2.757 & 0.007 & H0 is rejected \\
Company Size & -0.037 & 0.000 & -0.216 & 0.795 & H0 is accepted \\
\hline
\end{tabular}

Dependent variable $=$ BHAR5 Probability $=0.007$ and $\mathrm{R}^{2}=0.401$ 
Table 9: BHAR in the $2.5^{\text {th }}$ year ( $\left.\mathrm{t} 6\right)$

\begin{tabular}{lccccc}
\hline \multicolumn{1}{c}{ Variables } & Coefficient & Std. Error & t-Stat & Prob. & Result \\
\hline C & -38.071 & 12.239 & -3.111 & 0.003 & H0 is rejected \\
Age & 0.163 & 0.379 & 1.665 & 0.100 & H0 is accepted \\
TLAG & -0.025 & 0.012 & -0.268 & 0.790 & H0 is accepted \\
Issue Size & 0.473 & 0.000 & 3.619 & 0.001 & H1 is rejected \\
Company Size & 0.005 & 0.000 & 0.036 & 0.971 & H0 is accepted
\end{tabular}

Dependent variable $=$ BHAR6; Probability $=0.000$ and $\mathrm{R}^{2}=0.539$

Consistent with the previous condition, BHAR in the $5^{\text {th }}$ time point (in the $2^{\text {nd }}$ year) shows a significant condition where the p-value is 0.007. It is the same as the previous condition where only the Issue Size that significantly influences the long-run IPO performance positively. This condition means that actually all of the factors are related to or influence the long-run IPO performance in Indonesia, but only Issue Size that gives a significant influence, while the others are influencing the performance insignificantly.

In this data, this research has proven that a condition in $2.5^{\text {th }}$ year is also significant and is consistent with the previous condition, where the probability is 0.000 and only the Issue Size that significantly influ- ences the long-run IPO performance positively which is 0.473 . Based on the data, this research concludes that $\mathrm{HO}$ is rejected. This condition also proves that all factors are related to or influence the long-run IPO performance in Indonesia. However, since only Issue Size is significant, this factor influencing the long-run IPO performance significantly, while the other factors influence the condition insignificantly.

After three years listed in IPO, the condition shows that actually the factors influence the condition (the long-run IPO performance in Indonesia) because the regression is significant, but only the Issue Size factor that positively influences the long-run IPO performance which is 0.551 .

Table 10: BHAR in the $3^{\text {rd }}$ year ( $\left.\mathrm{t} 7\right)$

\begin{tabular}{llllll}
\hline Variables & Coefficient & Std. Error & t-Stat & Prob & Result \\
\hline C & -46.464 & 12.918 & -3.597 & 0.001 & H0 is rejected \\
Age & 0.178 & 0.400 & 1.907 & 0.060 & H0 is accepted \\
TLAG & -0.035 & 0.013 & -0.388 & 0.699 & H0 is accepted \\
Issue Size & 0.551 & 0.000 & 4.429 & 0.000 & H0 is rejected \\
Company Size & -0.032 & 0.000 & -0.253 & 0.801 & H0 is accepted \\
\hline
\end{tabular}

Dependent variable $=$ BHAR7 $;$ Probability $=0.000$ and $\mathrm{R}^{2}=0.597$ 
To give an explanation about the regression, this research will only discuss about the $3^{\text {rd }}$ year of Buy-and-Hold Adjusted Return. Moreover the explanation of this condition is also the same for the $1.5^{\text {th }}$ year, $2^{\text {nd }}$ year, and $2.5^{\text {th }}$ year, because those time points are defined as long-run period of IPO performance, and shows a significant condition. From the regression result summary, the regression equation is:

BHAR7 $=-46.464+0.178$ AGE -0.035 $\mathrm{TLAG}+0.551 \mathrm{IS}-0.032 \mathrm{CS}+\varepsilon \mathrm{i}$

From this regression equation, an assumption of each parameter could be derived that Age coefficient parameter $(\beta 1)=$ 0.178 . This condition means that on each one percent increase of BHAR, there would be an impact on 0.178 percent increase of Age percentage, with the assumption that TLAG, Issue Size (IS), and Company Size (CS) will remain the same.

Time Lag coefficient parameter $(\beta 2)$ $=-0.035$. This condition means that on each one percent increase of BHAR, there would be an impact on 0.035 percent decrease of TLAG percentage, with the assumption that Age, Issue Size (IS), and Company Size (CS) will remain the same.

Issue Size (IS) coefficient parameter $(\beta 3)=0.551$. This condition means that on each one percent increase of BHAR, there would be an impact on 0.551 percent increase of total share, with the assumption that Age, TLAG, and Company Size (CS) will remain the same.

Company Size (CS) coefficient parameter $(\beta 4)=-0.032$. This condition means that on each one percent increase of BHAR, there would be an impact on 0.032 percent decrease of total asset percentage, with the assumption that Age, TLAG, and Issue Size (IS) will remain the same.

Now, this research will discuss the result of the hypotheses testing for each variable one by one.
$\mathrm{H} 2$ : The older the firm, the better the longrun performance of IPO.

Table 7, 8 and 9 show conditions of BHAR of long-run IPO performance in Indonesia. From those tables, this research shows that age has a positive coefficient to the Buy-and-Hold Adjusted Return. It means that, the older the company in Indonesia, the better the long-run IPO performance. It is consistent with the hypotheses, where the old company will have lower underperformance condition. Moreover, this condition fails to explain that age influences the longrun performance of IPO significantly because the p-value shows an insignificant relationship. This condition is consistent with the research's result conducted by Goergen, et. al. (2007) that shows an insignificant result of age in influencing the long-run IPO performance positively, and the research conducted by Thomadakis, et. al. (2007) showing that age does not influence the long-run IPO performance. Hence, in this research HO is accepted.

This condition happens because investors in Indonesia do not consider the age of the company when they want to buy a share. Even though the previous research said that the age of the company will influence the availability of information about the company, but underwriter can be used to compose information available (Brav and Gompers, 1997). Thus, a young company is able to provide a lot of information in public. This condition can happen in Indonesia to avoid lack of information in the public.

H3: The longer the waiting period of a firm to go public, the lower the long-run performance.

The data above shows that time lag (TLAG) influences the long-run IPO performance negatively. It is consistent with the previous result that a long time period will make the investor get uncertainty, because 
they need more time to know the actual market value of their purchase security or before can liquidate it in the secondary market (Tsangarakis, 2004). Moreover, this research fails to explain a significant relationship within those conditions, because the pvalues are below $\alpha(0.05)$. It is constant with the research conducted by Gounopoulos, et. al. (2005), that time lag does not influence the long-run performance of IPO. Hence, in this research H0 is accepted. This insignificancy happens in Indonesia because time lag in Indonesia is almost the same in average. Thus, investors in Indonesia are not too worried to the long period between offer price and listing date.

H4: There is a positive relationship between the size of stock (number of share) at the going public period and its longterm performance.

Considering the hypotheses testing result, the data shows that the result is significant because $\mathrm{p}$-value from those three time points for long-run period are below 0.05 . The condition is also consistent with the hypotheses where there is a positive relationship between the Issue Size (IS) and its long-term performance. It is constant with the previous research findings. Hence, in this research $\mathrm{HO}$ is rejected.

Issue Size (IS) is a significant factor influencing long-run IPO performance in Indonesia positively. This condition shows that investors in Indonesia consider the total number of share offered in IPO. A company, which offers a high number of shares, indirectly shows that this company is a big company, because to issue a share, it needs a lot of money. Only big companies that are able to issue shares in a large number. It is easier for investors to know the reputation of the company from the number of the total share offered. That is why investors consider the number of share offered before they buy a share.
H5: The company size will influence the long-run performance positively.

Table 7, 8 and 9 show a condition that the Company Size (CS) does not influence the long-run IPO performance. It can be seen from the p-value which is more than $\alpha(0.05)$, while the coefficients are not the same one and another. At that time, the condition shows a positive relationship, while the other condition shows a negative relationship. Those conditions are not consistent with the previous research. A research conducted by Thomadakis, et. al. (2007) showed that CS influences the long-run IPO performance negatively. This is inconsistent with the previous research and hypotheses. Hence, in this research $\mathrm{H} 0$ is accepted.

This condition means that investors in Indonesia do not consider the total asset before they buy the share. It could happen because it is much easier to know the number of share offered and information about the company available in public, to define or judge the performance or reputation of the company. Thus, investors in Indonesia will only look at the information of number of share offered that can be used to interpret the size of the firms.

\section{Implications}

As discussed above, this research concludes that Indonesian Stock Exchange Market does not show a long-run IPO underperformance condition. Even though tStat of $\mathrm{t} 1$ (BHAR in the $1^{\text {st }}$ day) $>\mathrm{t}$-Stat of $\mathrm{t} 2$ (BHAR in the $6^{\text {th }}$ month) $>$ t-Stat of $\mathrm{t} 3$ (BHAR in the $1^{\text {st }}$ year) $>$ t-Stat of $t 4$ (BHAR in the $1.5^{\text {th }}$ year) $>\mathrm{t}$-Stat of $\mathrm{t} 5$ (BHAR in the $2^{\text {nd }}$ year) $>$ t-Stat of t6 (BHAR in the $2.5^{\text {th }}$ year) $>\mathrm{t}$-Stat of $\mathrm{t} 7$ (BHAR in the $3^{\text {rd }}$ year), but only $\mathrm{p}$-value in the $1.5^{\text {th }}$ year that shows a significant condition. It is inconsistent with the previous hypotheses. It can happen because the previous research finding conducted in countries that have worse condi- 
tions than Indonesia (Sri Lanka and Cyprus). Peter (2007) said that Sri Lanka's stock market is relatively small compared with the other country, even compared with some regional markets in South Asia, while Cypriot is the smallest market the international evidence that has ever searched (Gounopoulos, et. al., 2005).

The other results also show that all of the factors influence or are related with the long-run IPO performance in Indonesia, but only the Issue Size that influences the longrun IPO performance significantly. This research has proven that those four factors are influencing $59.7 \%$ of this model, while $40.3 \%$ are influenced by other factors.

Age of the Company (AGE) influences long-run IPO performance positively until the third year after IPO. It means that, the older the company in Indonesia, the better the long-run IPO performance. It is consistent with the hypothesis, where the old company will have lower underperformance condition. But this research shows that this condition is not significant, or it means that age does not influence the long-run IPO performance in Indonesia significantly. It is constant with Thomadakis, et. al (2007) showing that age does not influence the long-run IPO performance.

Time Lag (TLAG) influences longrun IPO performance negatively. It means that the longer the waiting time period, the lower the long-run IPO performance. This condition indicates that company should not make longer waiting period, because this can make the investor worried. Moreover, this factor does not influence long-run IPO performance in Indonesian Stock Market significantly, thus $\mathrm{HO}$ is accepted. It is constant with the research conducted by Gounopoulos, et. al. (2005) that is time lag does not influence the long-run performance of IPO.

Issue Size (IS) is the only factor in this research influencing long-run IPO per- formance significantly. It happens since the $1.5^{\text {th }}$ year after go public because long-run period of IPO is defined as one year after go public. It is consistent with the previous findings and the hypotheses. It means the more the number of shares offered, the better the long-run IPO performance.

Company Size (CS) influences the long-run IPO underperformance in Indonesian Stock Exchange Market insignificantly. In one time point, the condition shows a positive relationship, but in the other time point shows a negative condition. It is consistent with the result found by Thomadakis, et. al. (2007).

For investors in Indonesia, the implication of this research can be an indicator. Even though the long-run underperformance in Indonesia does not show a significant condition, but the condition tends to be declined if seen from the compare t test's result. It has proven that the condition in Indonesia is easier to be worse (the underperformance significantly happen in Indonesia) when the economic condition is getting worse. Thus, investors in Indonesia should be more careful before they decide to invest in IPO activity. The investors should also be more careful with the factors influencing the long-run IPO performance. Even though, from those four factors, only Issue Size influencing the long-run IPO performance significantly, but other factors actually are also related with the long-run performance. On the other hand, those four factors only influence $59.7 \%$ of the method, while the $40.3 \%$ are influenced by other factors. It could be the political factor, economical factor, government regulation, etc. Since Indonesia is an emerging market that is very sensitive with those factors. And the way to invest in Indonesia could be different from the way to invest in America or Europe.

For company, this research can be used, thus company can be more careful in making go public decision. Company should 
know what factors are influencing the longrun IPO performance. By knowing the influencing factors, company can prevent a negative condition that may occur in the future, for example, to give a short waiting period for the investor, to issue higher number of share, to become old enough before go public, etc. This activity can help reducing the negative effect of those factors to the longrun IPO performance. Hopefully, IPO activity can be a good activity for a company to raise fund from the investor, because by making the investor trusts the company to invest in, the company can get fund from the public easier.

For the researcher, this research shows that those four factors only influence this method $59.7 \%$, while the other $40.3 \%$ are influenced by other factors. This condition means that there are still a lot of factors that must be found, which factors influencing the long-run IPO performance in Indonesia. Thus, more information for the company and also investor to get better long-run IPO performance in the future can be provided.

\section{CONCLUSIONS AND RECOMMENDATIONS}

This session provides some conclusions and recommendations based on the analysis, which have been undertaken in the previous chapter. This research conducts an analysis of long-run IPO performance in Indonesian Stock Market using companies listed in Indonesia Stock Market during 2000-2005. This data is expected to be a good data, because company's conditions are relatively stable after 1998 crisis and before 2007 crisis. From 103 companies listed in Indonesian Stock Exchange Market during 2000-2005, only 84 companies fulfill the requirement, thus they can be used as the sample. This research is finding the long-run IPO performance and measuring factors that influence the performance, which are age, time lag, total share, and total asset of the company.

Having done a test and analysis, the general conclusion of this research is that Indonesian Stock Exchange Market does not show underperformance long-run IPO. From the variable used, the results show that there is a positive relationship between the issue size (number of share) at the going public period and its long-term performance. However, the other variables used (age, time lag, and company size) do not influence the long-run IPO performance in Indonesian Stock Exchange Market. It is constant with the finding of Thomadakis, et. al. (2007) and Gounopoulos, et. al. (2005). The conclusions are:

1. There is no significant long-run IPO underperformance in Indonesia. However during the research period, it is proved that the condition shows a declining IPO performance, because the IPO performance is getting worse yearto-year.

2. All of the factors are influencing the long-run IPO performance, but only Issue Size influencing it significantly.

3. From the hypotheses:

a. Indonesian Stock Exchange Market does not show underperformance longrun IPO.

b. The company age does not influence positively the long-run performance of IPO.

c. Time lag does not influence negatively the long-run performance of IPO.

d. The size of stock at the go public period influences positively the long-term performance.

e. Company size does not influence the long-run underperformance of IPO in Indonesia.

4. Investors in Indonesia do not really consider those factors before they buy the share, but the total number of stock offered is something easy to think be- 
fore deciding to buy the share, and indirectly related to the size and the reputation of the company.

The result of this study is not too successful to show the influencing factors really have relationship with the long-run IPO performance in Indonesian Stock Exchange Market. It might be because the period used is too short or the other factors that could influence the investment condition in Indonesia. So, this study gives the following recommendations. For researcher

The next researcher can extend the period become longer one, for example five years after go public, or other longer periods. It is suggested for the next researcher to add variables, such as under writer, hot-cold market condition, ownership structure, security factor, and shareholder decision, or macroeconomic factor such as inflation and currency rates, and government regulations. It is better for the next researcher to use other methods, such Fama-French's, Average Monthly Adjusted Return (MMAR), or Tobin's $Q$ method to provide different condition. b. For investor

Even though there is no proved that long-run IPO performance shows a significant underperformance condition, but the condition indicates that the IPO performance is getting worse year-to-year. Thus, it is better for the investors not to hold the stock in long time period, but in short time period. Because the IPO performance in long-term is getting worse and it is too risky to hold the stock in long period.

\section{REFERENCES}

Alvarez, S., and Gonzalez, V.M. (2001). Long-run performance of initial public offering (IPOs) in the Spanish Capital Market. Working Paper, University of Oviedo. Retrieved October 6, 2008, from http://papers.ssrn.com/sol3/papers.c fm?abstract_id=274086
Bessler, W., and Thies, S. (2007). The Long-run performance of initial public offerings in Germany. [Electronic Version]. Managerial Finance, 33(6), 420-441.

Bradley, D.J., Cooney, J.W., Dolvin, S.D., and Jordan, B.D. (2006). Penny stock IPOs. [Electronic Version]. Financial Management, 35(1), 530.

Brav, A., and Gompers, P.A. (1997). Myth or reality? The long-run underperformance of initial public offerings: evidence from venture and nonventure capital-backed companies. The Journal of Finance, 52(4), 19711821.

Chahine, S. (2007). Block-holder ownership, family control and post-listing performance of French IPOs. [Electronic Version]. Managerial Finance, 33(6), 388-400.

Chin, C.L., Lee, P., Kleinman, G., and Chen, P.Y. (2006). IPO anomalies and innovation capital. [Electronic Version]. Review of Quantitative $F i$ nance and Accounting, 27(1), 6791.

Corhay, A., Teo, S., and Rad, A.T. (2002). The long run performance of Malaysian Initial Public Offerings (IPOs): value and growth effects. [Electronic Version]. Managerial Finance, 28(2), 52-66.

Dempere, J.M. (2008). Self-underwritten IPOs. [Electronic Version]. Journal of Global Business and Technology, 4(1), 1-18.

Dimovski, W., and Brooks, R. (2004). Initial Public Offerings in Australia 1994 to 1999 , recent evidence of underpricing and underperformance. 
[Electronic Version]. Review of Quantitative Finance and Accounting, 22(3), 179-199.

Drobetz, W., Kammermann, M., and Walchli, U. (2005). Long-run performance of initial public offerings: the evidence for Switzerland. [Electronic Version]. Schmalenbach Business Review, 57, 253-275.

Eckbo, B.E., and Norli, O. (2004). Liquidity risk, leverage and long-run IPO returns. [Electronic Version]. Tuck School of Business Working Paper No. 2004-14, Journal of Corporate Finance, 11, 1-35.

Goergen, M., and Renneboog, L. (2007). Does ownership matter? A study of German and UK IPOs. [Electronic Version]. Managerial Finance, 33(6), 368-387.

Goergen, M., Khurshed, A., and Mudambi, R. (2007). The long-run performance of UK IPOs can it be predicted? [Electronic Version]. Managerial Finance, 33(6), 401419.

Gounopoulos, D., Nounis, C., and Stylianides, P. (2005). The short and long term performance of Initial Public Offering in the Cyprus Stock Exchange. Working Paper, University of Surrey, University of Athens and City Univesity $\mathrm{R}$ trieved October 8, 2008, from http://papers.ssrn.com/sol3/papers.c fm? abstract_id $=1002974$

Gu, A.Y. (2003). State ownership, firm size, and IPO performance-evidence from Chinese-a-share issues. [Electronic Version]. American Business Review, 21(2), 101-109.

Gujarati, Damodar and Zain, Sumarno.
(1988). Ekonometrika dasar. Jakarta.

Guo, R.J., Lev, B., and Shi, C. (2005). Explaining The short and long-term IPO anomalies in the US by RandD. NYU Working Paper No. 2451/27474, UIC College of Business Administration Research $\mathrm{Pa}$ per No. 08-02. Retrieved September 19, 2008, from http://papers.ssrn.com/sol3/papers.c fm?abstract_id=1280695

Jaskiewicz, P., Gonzalez, V.M., Menendez, S., and Schiereck, D. (2005). Longrun IPO performance analysis of German and Spanish family-owned businesses. [Electronic Version]. Family Business Review, 18(3), 179-193.

Keown, A.J., Martin, J.D., Petty, J.W., and ScottJr, D.F. (2005). Financial Management: Principle and Application $\left(10^{\text {th }}\right.$ ed.). New Jersey: Pearson Prentice Hall.

Li, L., and Hovey, M. (2007). Does IPO underpricing in China explain a firm's long-term performance? Working Paper, La Trobe University and University of Southern Queensland. Retrieved October 23, 2008, from http://papers.ssrn.com/sol3/papers.c fm?abstract_id=1009417

Peter, S. (2007). Performance of Initial Public Offerings and Privatized Offers, evidence from a developing country. [Electronic Version]. Managerial Finance, 33(10), 798-809.

Pracianoy, J.L., and Cigerza, G.C. (2007). IPOs in emerging markets: a comparison of Brazil, India and China. Working Paper Universidade Federal do Rio. 